\title{
COUNTERPRODUCTIVE WORK BEHAVIOR. COMPARISON OF THE PUBLIC AND PRIVATE SECTOR [1]
}

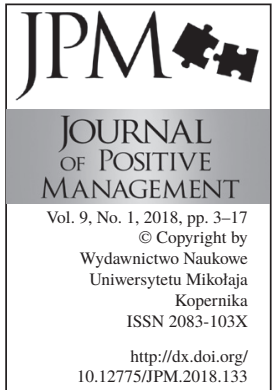

\author{
Nicalaus Copernicus University in Torun, Faculty of Economic Sciences \\ and Management, Torun, Poland \\ e-mail: dawidsz@umk.pl
}

\begin{abstract}
Purpose: The main purpose of the article is to verify a hypothesis that the public sector employees tend to engage in counterproductive behavior (CWB) at work more often than the private sector employees. An additional purpose is to present results of the research relating to frequency of engagement of employees in CWB in Poland.

Methodology: The research was conducted in 2017 with the use of an online questionnaire method with respect to 535 employees from all regions of Poland. The data were analysed with the use of IBM SPSS application.
\end{abstract}

Findings: Based on analysis of the research results (an analysis of frequency and Pearson's chisquare coefficients) it has been found that there are no grounds for rejection of the hypothesis. This relationship was also observed in relation to particular manifestations, categories and dimensions of these behaviors.

Implications/limitations: The research paper includes precious hints for managers working mainly in the public sector. Considering the research results, they should undertake particularly active CWB risk reducing activities in their organizations. It is also necessary to monitor appearance of such behaviors on an ongoing basis as well as identify reasons for such behaviors.

The main limitations of the research include biased character of the sample resulting from its nonrandom selection and limited control over the process of research resulting from a method of data collection.

A future research should involve a representative sample with the use of quantitative and qualitative methods, which will allow to extend the level of analysis and identify reasons for differences in manifestation of CWB by employees of both sectors.

Originality/value: The research paper fills a gap in the literature relating to differences in tendencies to manifest CWB among the public and private sector employees in Poland. Despite the fact that the problem has already been emphasized by various authors, there are no comprehensive research results concerning the same.

Keywords: counterproductive work behavior, organizational behavior, private sector, public sector

Paper type: Research paper 
COUNTERPRODUCTIVE

WORK

BEHAVIOR

Dawid Szostek

\section{Introduction}

In the USA losses resulting from counterproductive work behaviors (CWB) amount to 6 or even 200 billion USD. What is more, as many as 33-75\% of American workers admit engagement in such activities as thefts, embezzlement, vandalism, sabotage or unjustified absence (Robinson and Bennett, 1995). Media report very often on detecting a corrupt worker or cases of violence at the place of work.

CWB is manifested in every organization, regardless of a longitude or latitude. This results from an imperfect nature of human beings and impossibility to foresee their responses to various conditions. However, one may indicate certain sectors of the economy, in which such types of behaviors are manifested most often. This is the case of the public administration sector as compared to the private sector workers (Burned and Pope, 2007). This is a kind of a paradox, as the first of them is a higher public trust sector and, as such, it should be characterised by higher ethical standards (Ikola-Norrbacka, 2010).

As a reason for this difference, authors point, among others, to little mobility of the public sector workers, which makes them more susceptible to such behaviors as mobbing or bullying (Zapf et al., 2003). The reasons could also include organizational structures burdened by red tape and depersonalization, autocratic management style, gaps in internal communications and salaries lower than those paid to the private sector workers, which results in a lower level of satisfaction and higher level of frustration or willingness to retaliate (Leymann, 1996; Nasir and Bashir, 2012; Bibi et al., 2013).

Unfortunately, the world literature does not include any exhaustive research on this subject (Nasir and Bashir, 2012). What is more, none of researchers have confirmed it empirically that there is a difference as regards frequency of manifestation of counterproductive behaviors by the public and private sector workers in Poland. Thus, the above constitutes a significant gap in knowledge, which author has attempted to fill.

The main purpose of the research paper is to verify the hypothesis that the public sector employees tend to engage in counterproductive work behaviors more often that the private sector employees. An additional purpose is to present results of the research relating to the frequency of engagement of employees in CWB in Poland. The research was conducted in 2017 with the use of an online questionnaire method with respect to 535 active employees (including 280 workers from the private sector and 244 workers from the public sector [2]).

\section{Counterproductive behaviors and their consequences}

The literature includes various definitions of counterproductive behaviors. However CWB is most often referred to in publications and seems to be the most adequate term of such behaviors (Glińska-Neweś and Lis, 2016), which is mainly 
due to the fact that it constitutes (a substantive and semantic) counterbalance for extraproductive behaviors (positive behaviors also referred to as Organizational Citizenship Behaviors, OCB; Organ, 1997). The absence of coherence as regards terms and definitions makes it difficult to understand the phenomenon as well

COUNTERPRODUCTIVE WORK BEHAVIOR

Dawid Szostek as compare results of research conducted by various authors and evaluate the current status of the knowledge about these behaviors. They are referred to as bad, negative, pathological, dysfunctional, retaliate or unethical (Szostek, 2017). Not all of the definitions express it properly what such types of behaviors are, although the major common characteristic of such behaviors is that they infringe rules and norms of an organization or make it impossible to reach its goals (Nerdinger, 2011). However, for counterproductive behaviors to be manifested, additional conditions have to be fulfilled.

Thus, Spector et al. (2006) define CWB as a collection of some activities characterized by voluntariness (contrary to accidental or forced activities) that are or may be detrimental to an organization or various groups of its stakeholders (e.g. customers, workers, managers) (see also Robinson and Bennett, 2005; Sharma and Thakur, 2016). The behaviors can be of various significance, starting from petty misconduct (such as gossiping, theft of corporate pens) and ending with serious offences (such as verbal/physical aggression aimed at a colleague, sexual harassment or swindling).

Counterproductive behaviors result from internal (e.g. personality) and external/contextual conditions (such as organizational culture, environment, social permission) relating to a worker (Penney et al., 2011). Negative consequences of the behaviors may affect a worker or organization itself and, thus, also economies and societies (Warrne, 2003) [3] (see Table 1).

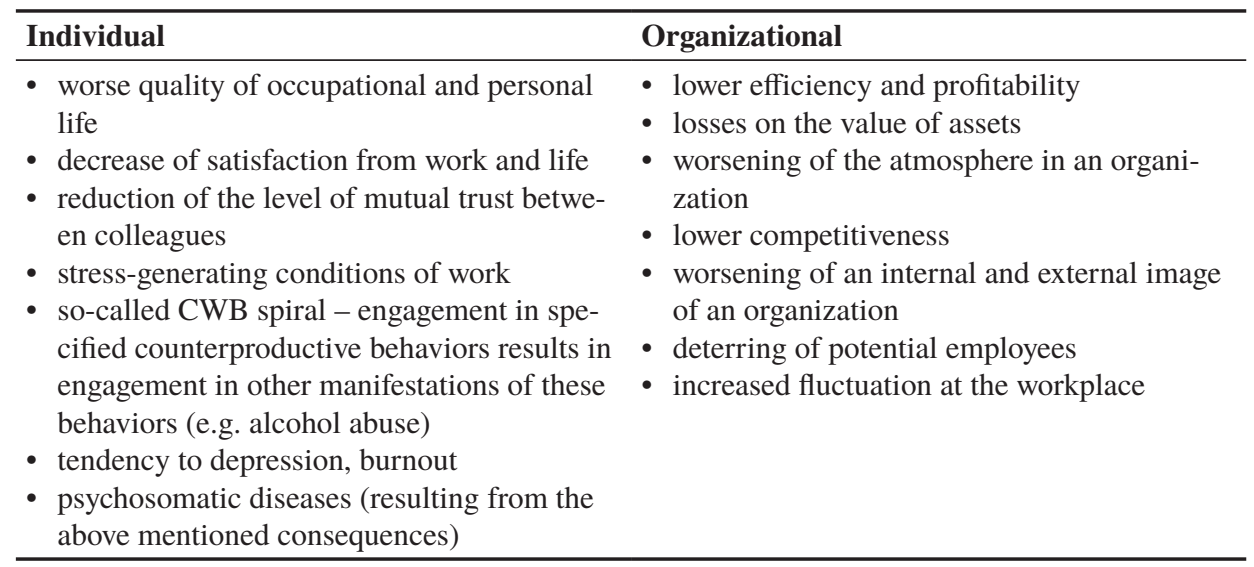

Table 1. Examples of consequences of counterproductive behaviors

Source: own elaboration based on: Everton and Jolton, 2007; Penney et al., 2011; Sharma and Thakur, 2016. 
COUNTERPRODUCTIVE

WORK

BEHAVIOR

Dawid Szostek

Figure 1. Typology of deviant behaviors according to

Robinson and

Bennett

Source: Robinson and Bennett, 1995.

\section{Typology of counterproductive behaviors}

The literature differentiates among numerous classifications of counterproductive work behaviors (see e.g. Whellet, 1976; Vardi and Weitz, 2004), although not all of them seem to describe the phenomenon in an exhaustive and separate manner. Some of them only indicate most often mentioned manifestations of CWB and do not combine them in logically coherent categories (e.g. Gruys and Sackett, 2003). The first comprehensive classification was proposed by Robinson and Bennett (1995) (the authors referred to the deviant behaviors). Considering two basic dimensions, i.e.:

1) serious vs minor behaviors,

2) organizational or interpersonal behaviors, the authors differentiated among four basic categories of deviances at work (see Figure 1):

1) production deviance - i.e. wasting of resources, leaving work earlier without a permission, taking extended breaks,

2) property deviance - i.e. theft of corporate property, corruption, sabotage,

3) political deviance - e.g. nepotism, gossiping, blaming others for one's mistakes, unfair competition,

4) personal aggression - e.g. sexual harassment, verbal violence, stealing property of colleagues or undertaking activities that threaten others.

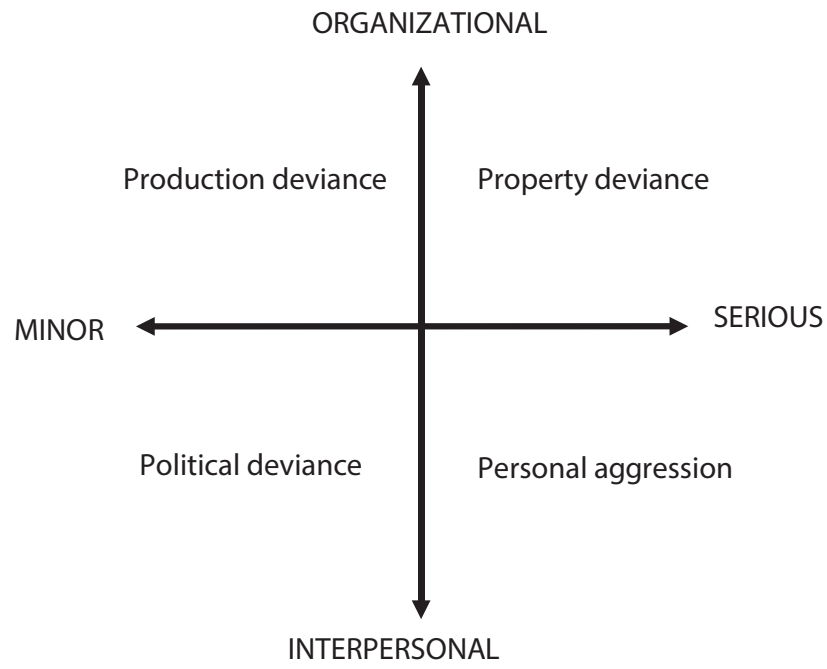

The typology suggested by Robinson and Bennett (1995) belonged to most often used typologies used in the researches. Presently, the role has been assumed by the classification of CWB suggested by Spector et al. (2006), which differentiated among five categories of these behaviors: 
1) abuse against others - activities aimed at harming other people in an organization (most often) psychically or (rarely) physically by (e.g.) making spiteful comments, threatening, ignoring or hindering effective work,

2) production deviance - resulting in intentional limitation of effectiveness and efficiency of an organization,

3) theft - misappropriation of corporate property or property of other people at work (e.g. colleagues) without a permission. It is one of the most often found manifestations of CWB,

4) sabotage - intentional damaging or destroying of components of corporate property, including both tangible (such as machines) and non-tangible property (e.g. the image of an organization). The behavior can be understood as a more active form of production deviance,

5) withdrawal - involves limitation of time of work below minimum time necessary for realization of organizational targets (e.g. being late for work, extending breaks without permission of supervisor, unjustified absences). Contrary to other types of CWB, withdrawal involves a failure to engage in some activities and not engagement in specified activities.

The typology suggested by Spector et al. (2006) also divides CWB into two basic dimensions, i.e. the behaviors may harm other individuals (CWB-I) or an organization (CWB-O).

\section{Research methodology}

The author used his own research results in order to accomplish the purposes set. The research was conducted with the use of an online questionnaire in 2017 and involved a non-random sample of occupationally active employees. The selection of a sample was intentional, i.e. a request for participation in the survey and a link to the questionnaire [4] was sent in May and November to:

- working students of the Faculty of Economic Sciences and Management of Nicolaus Copernicus University of Torun,

- employees of rural, urban and urban-rural communes [5] cooperating with the author,

- the author's friends and acquaintances.

Each of the groups was also asked to propagate information about the survey among other occupationally active people they knew. Despite the fact that the sample was not selected randomly and, therefore, it was not representative, the results obtained have a great value and make it possible to observe significant regularities and draw conclusions relating to the hypothesis set (mainly due to a numerous sample).

Finally, a group qualified for analysis included 535 employees (its detailed characteristics are included in Table 2). 
COUNTERPRODUCTIVE

WORK

BEHAVIOR

Dawid Szostek

Table 2.

Characteristics of respondents

Source: own research.

\begin{tabular}{|c|c|c|c|c|c|c|c|}
\hline & & \multicolumn{2}{|c|}{ Private sector } & \multicolumn{2}{|c|}{ Public sector } & \multicolumn{2}{|l|}{ Total } \\
\hline & & Number & $\%$ & Number & $\%$ & Number & $\%$ \\
\hline \multirow{3}{*}{ Sex } & Women & 184 & 65.7 & 184 & 75.4 & 372 & 69.5 \\
\hline & Men & 96 & 34.3 & 60 & 24.6 & 163 & 30.5 \\
\hline & Missing data & 0 & 0 & 0 & 0 & 0 & 0 \\
\hline \multirow{5}{*}{ Age } & $18-25$ & 182 & 65.0 & 53 & 21.7 & 246 & 46.0 \\
\hline & $26-35$ & 39 & 13.9 & 28 & 11.5 & 67 & 12.5 \\
\hline & $36-45$ & 9 & 3.2 & 91 & 37.3 & 100 & 18.7 \\
\hline & $46-55$ & 16 & 5.7 & 5 & 2.0 & 21 & 3.9 \\
\hline & Missing data & 34 & 12.1 & 67 & 27.5 & 101 & 18.9 \\
\hline \multirow{5}{*}{ Education } & Vocational & 4 & 1.4 & 0 & 0 & 4 & 0.7 \\
\hline & Secondary & 41 & 14.6 & 11 & 4.5 & 52 & 9.7 \\
\hline & Higher & 90 & 32.1 & 164 & 67.2 & 261 & 48.8 \\
\hline & During studies & 145 & 51.8 & 69 & 28.3 & 218 & 40.7 \\
\hline & Missing data & 0 & 0 & 0 & 0 & 0 & 0 \\
\hline \multirow{4}{*}{$\begin{array}{l}\text { Position } \\
\text { held }\end{array}$} & Managerial workers & 21 & 7.5 & 0 & 0 & 21 & 3.9 \\
\hline & Administrative/Office workers & 153 & 54.6 & 141 & 57.8 & 305 & 57.0 \\
\hline & $\begin{array}{l}\text { Operational workers (e.g. } \\
\text { service production) }\end{array}$ & 106 & 37.9 & 103 & 42.2 & 209 & 39.1 \\
\hline & Missing data & 0 & 0 & 0 & 0 & 0 & 0 \\
\hline \multirow{4}{*}{$\begin{array}{l}\text { Type of } \\
\text { employ- } \\
\text { ment }\end{array}$} & $\begin{array}{l}\text { Contract (for specified or } \\
\text { unspecified period) }\end{array}$ & 145 & 51.8 & 204 & 83.6 & 360 & 67.3 \\
\hline & Civil law agreement & 115 & 41.1 & 16 & 6.6 & 131 & 24.5 \\
\hline & Other & 20 & 7.1 & 16 & 6.6 & 36 & 6.7 \\
\hline & Missing data & 0 & 0 & 8 & 3.3 & 8 & 1.5 \\
\hline \multirow{3}{*}{$\begin{array}{l}\text { Working } \\
\text { hours }\end{array}$} & Full-time job & 146 & 52.1 & 200 & 82.0 & 357 & 66.7 \\
\hline & Part-time job & 49 & 17.5 & 36 & 14.8 & 85 & 15.9 \\
\hline & Unlimited working hours & 85 & 30.4 & 8 & 3.3 & 93 & 17.4 \\
\hline 33 & vate sector $=280 / 52.3 \%$. public & tor $=2$ & $4 / 45.6$ & $\operatorname{missin}$ & ata $=$ & $/ 2.1 \%)$ & \\
\hline
\end{tabular}

\section{Discussion}

The author used a scale of 22 items taken from a validated and commonly used scale suggested by Spector et al. (2006) - so-called Counterproductive Work Behavior Checklist (CWB-C) - see appendix 1. The respondents were asked to comment on each item, indicating frequency of engagement in a given behavior (never; 1-2 times; 1-2 times a month; 1-2 times a week; every day). The basic version of the scale includes 45 items divided into 5 above-mentioned CWB categories [6]. The used scale was characterized by high reliability both for 
particular categories of CWB and CWB as a whole [7]. What is more, selected items seemed to be most comprehensible in Polish cultural conditions.

The respondents (regardless of a sector they were employed in) tended to be most often engaged in less serious categories of counterproductive work behaviors. Such behaviors included, most of all, withdrawal (45.6\% for the aggregate number of "never" answers and $20.8 \%$ for the sum of "1-2 times a month/week" and "every day" answers), including also such manifestations as being late for work, unpermitted extension of breaks and leaving one's work earlier. The respondents tended to engage in abuses towards other a little less frequently $(61.3 \%$ and $11.7 \%$ - see above) and mainly in less significant forms of such behaviors (e.g. offending someone, making fun of somebody, being rude). However, the least frequently manifested behaviors belonging to CWB category included sabotage $(81.1 \%$ and $7.7 \%$, including: intentional destroying of corporate equipment/property, dirtying or littering the place of work and wasting of the employer's resources), production deviance $(68.1 \%$ and $8.8 \%)$ as well as thefts $(67.6 \%$ and $11.6 \%)$.

The appendix 2 (charts from 1 to 8 ) presents the frequency of CWB, the frequency of particular CWB-categories as well as the frequency of CWBdimensions (divided, in each case, into the public and private sectors).

Analysing the presented results, it can be noted that the public sector workers seem to be engaged more in CWB than the private sector workers. This also applies to particular categories of counterproductive behaviors and each of dimensions of CWB. Even if the private sector workers manifest such behaviors, the behaviors are incidental. On the other hand, in the public sector CWBs are more regularly manifested.

In order to determine, whether the relationship between frequency of engagement in CWB and the type of a sector, in which a given respondent is employed, is significant statistically, Pearson's chi-square coefficient was applied (see Table 4). As in each case (for particular categories/dimensions of CWB and for CWB as a whole) the value of significance is lower than the adopted level of significance, namely $\alpha=0.05$, the hypothesis relating to independence of the variables analysed can be rejected in favour of an alternative hypothesis assuming that there is such relationship (the variables are dependent).

\begin{tabular}{lccc}
\hline A sector of employment vs. & Chi-square & Df & Significance \\
\hline$\ldots$ CWB & 24.778 & 5 & $.000^{*}$ \\
\hline ...abuse & 27.166 & 5 & $.000^{*}$ \\
\hline ...production deviance & 32.246 & 5 & $.000^{*}$ \\
\hline ...sabotage & 51.032 & 5 & $.000^{*}$ \\
\hline ...theft & 36.786 & 5 & $.000^{*}$ \\
\hline
\end{tabular}

COUNTERPRODUCTIVE WORK BEHAVIOR

Dawid Szostek
Table 4. Pearson's chi-square coefficients for the relationship between the sector of employment and

CWB (including categories and dimensions of CWB)

Source: own research. 
COUNTERPRODUCTIVE

WORK

BEHAVIOR

Dawid Szostek

Table 4.

continued

\begin{tabular}{lccc}
\hline A sector of employment vs. & Chi-square & Df & Significance \\
\hline ...withdrawal & 24.778 & 5 & $.000^{*}$ \\
\hline ..CWB-I & 30.554 & 5 & $.000^{*}$ \\
\hline ..CWB-O & 22.070 & 5 & $.001^{*}$ \\
\hline
\end{tabular}

*Chi-square statistics are significant for $\alpha=0.05$

\section{Conclusions}

Based on the research it can be stated that there are no grounds for rejection of the hypothesis made by the author that the public sector workers tend to be more often engaged in counterproductive work behaviors that the private sector workers in Poland. This applies both to CWB as a whole and particular categories and dimensions of such types of behaviors distinguished by Spector et al. (2006). An additional value of the publication includes the presented results of the research in relation to frequency of engagement in such activities by the respondents. It is clear that workers (of both sectors) tended to engage most frequently in less serious manifestations of CWB (e.g. withdrawal) and least frequently in more serious manifestations of them (e.g. sabotage).

To conclude, it should be mentioned some of limitations of the research conducted. It include, most of all, the non-random character of the sample selected, due to which the conclusions cannot be generalised over the population and, therefore, these conclusions should be treated cautiously. The biased character of the sample is proved by the fact that nearly $90 \%$ of the respondents had higher or incomplete higher education.

The research method (an online questionnaire) also gave the researcher a limited opportunity to control the process of data collection. Therefore, it is not possible to consider a lot of variables that could affect the research and, consequently, reliability of results obtained. Finally, the research did not identify factors that conditioned differences in answers given by the private and public sector workers. Therefore, future research should certainly be conducted on a representative sample with the use of quantitative and qualitative methods allowing for extension of the level of analysis.

Despite the drawbacks discussed, the author expresses his hope that Readers will view this publication favourably and the publication will inspire both practitioners and theoreticians of management. If this should be the case, all efforts made will not prove to be futile. 


\section{Notes}

[1] The project was funded by the National Science Centre, Poland, on the decision number DEC-2017/25/B/HS4/01113.

[2] 11 respondents did not indicate the type of a sector, in which they were employed.

[3] It should be noted that the literature also refers to positive aspects of negative behaviors in an organization, referring to the same as constructive deviations, which are manifested, when current standards of an organization are infringed and it results in benefits for the organization itself and/or various groups of its stakeholders (see e.g. Warren, 2003).

[4] The questionnaire is available at: https://goo.gl/forms/xCcNp0QCO3Mvhj6E2.

[5] The cooperation relates to business activity of the author - see: www.CentrumFunduszyUE.pl.

[6] Two other versions of the scale are based on 32 and 10 items. The scale is available in English, German, Hebrew, Romanian, Spanish and Urdu. The Polish language version has been translated by the author - CWB-C, http://shell.cas.usf.edu/ pspector/scales/cwbcpage.html.

[7] This was proved by values of Cronbach's Alpha coefficient: 0.784 (for 'abuse' category), 0.427 (production deviance), 0.623 (sabotage), 0,751 (theft), 0,567 (withdrawal), 0,876 (for all CWB categories jointly).

\section{References}

Bibi, Z., Karim, J., ud Din, S. (2013), “Workplace Incivility and Counterproductive Work Behavior: Moderating Role of Emotional Intelligence”, Pakistan Journal of Psychological Research, Vol. 28 No. 2, pp. 317-334.

Burned, B., Pope, R. (2007), "Negative behaviors in the workplace: A study of two Primary Care Trusts in the NHS", International Journal of Public Sector Management, Vol. 20 No. 4, pp. 285-303. DOI: 10.1108/09513550710750011

Counterproductive Work Behavior Checklist (CWB-C), available at: http://shell.cas.usf. edu/ pspector/scales/cwbcpage.html (accessed 21 November 2017).

Everton, W.J., Jolton, J.A., Mastrangelo, P.M. (2007), "Be nice and fair or else: understanding reasons for employees' deviant behaviors", Journal of Management Development, Vol. 26 No. 2, pp. 117-131. DOI: 10.1108/02621710710726035

Glińska-Neweś, A., Lis, A. (2016), „Paradoks współwystępowania organizacyjnych zachowań obywatelskich i kontrproduktywnych", Prace Naukowe Uniwersytetu Ekonomicznego we Wroctawiu, No. 422, pp. 265-274.

Gruys, M.L., Sackett, P.R. (2003), "Investigating the Dimensionality of Counterproductive Work Behavior", International Journal of Selection and Assessment, Vol. 11 No. 1, pp. 30-42. DOI: 10.1111/1468-2389.00224

Ikola-Norrbacka, A.S.R. (2010), “Trust. good governance and unethical actions in Finnish public administration", International Journal of Public Sector Management, Vol. 23 No. 7, pp. 647-668. DOI: 10.1108/09513551011078905.

Leymann, H. (1996), “The content and development of mobbing at work", European Journal of Work and Organizational Psychology, Vol. 5 No. 2, pp. 165-184. DOI: $10.1080 / 13594329608414853$

Nasir, M., Bashir, A. (2012), "Examining workplace deviance in public sector organizations of Pakistan", International Journal of Social Economics, Vol. 39 No. 4, pp. 240-253. DOI: $10.1108 / 03068291211205677$

Nerdinger, F.W. (2011), "Formen des Arbeitsverhaltens", in: Nerdinger, F.W., Blickle,
COUNTERPRODUCTIVE

WORK

BEHAVIOR

Dawid Szostek 
COUNTERPRODUCTIVE WORK

BEHAVIOR

Dawid Szostek
G., Schaper, N. (Eds.), Arbeits- und Organisationspsychologie. Springer-Lehrbuch, Springer, Berlin, Heidelberg.

Organ, D.W. (1997), "Organizational Citizenship Behavior: It's Construct Clean-Up Time”, Human Performance, Vol. 10 No. 2, pp. 85-97. DOI: 10.1207/s15327043hup1002_2

Penney, L.M., Hunter, E.M., Perry, S.J. (2011), "Personality and counterproductive work behavior: Using conservation of resources theory to narrow the profile of deviant employees", Journal of Occupational and Organizational Psychology, Vol. 84, pp. 58-77. DOI: 10.1111/j.2044-8325.2010.02007.x

Robinson, S.L., Bennett, R.J. (1995), “A Typology of Deviant Workplace Behaviors: A Multidimensional Scaling Study”, Academy of Management Journal, Vol. 38 No. 2, pp. 555-572. DOI: 10.2307/256693

Sharma, A., Thakur, K. (2016), "Counterproductive Work Behavior: The Role of Psychological Contract Violation”, International Journal of Multidisciplinary Approach and Studies, Vol. 3 No. 1, pp. 13-27.

Spector, P.E., Fox, S., Penney, L.M., Bruursema, K., Goh, A., Kessler, S. (2006), “The dimensionality of counterproductivity: Are all counterproductive behaviors created equal?", Journal of Vocational Behavior, Vol. 68, pp. 446-460. DOI: 10.1016/j.jvb.2005.10.005

Szostek, D. (2017), "The Use of Marketing Research in Internal Marketing. The Methods of Measurement of Counterproductive Work Behaviors in an Organization", Annales Universitatis Mariae Curie-Skłodowska. Sectio H OECONOMIA, Vol. LI No. 2, pp. 245-252. DOI: 10.17951/h.2017.51.2.245

Vardi, Y., Weitz, E. (2004), Misbehavior in Organizations, Lawrence Elbaum Associates, New Jersey.

Warren, D.E. (2003), "Constructive And Destructive Deviance In Organizations", Academy of Management Review, Vol. 28 No. 4, pp. 622-632. DOI: 10.5465/AMR.2003.10899440 Wheeler, H.N. (1976), "Punishment theory and industrial discipline", Industrial Relations, Vol. 15 No. 2, pp. 235-243. DOI: 10.1111/j.1468-232X.1976.tb01120.x

\section{Appendix 1. The scale use in the research on CWB}

\begin{tabular}{lll}
\hline $\begin{array}{lll}\text { CWB cate- } \\
\text { gories }\end{array}$ & Items & CWB-I/O \\
\hline \multirow{4}{*}{ Abuse } & Started or continued a damaging or harmful rumor at work & $\mathrm{I}$ \\
\cline { 2 - 3 } & Been nasty or rude to a client or customer & $\mathrm{I}$ \\
\cline { 2 - 3 } & Blamed someone at work for error I made & $\mathrm{I}$ \\
\cline { 2 - 3 } & Started an argument with someone at work & $\mathrm{I}$ \\
\cline { 2 - 3 } & Threatened someone at work & $\mathrm{I}$ \\
\cline { 2 - 3 } & Hit or pushed someone at work & $\mathrm{I}$ \\
\cline { 2 - 3 } & Insulted or made fun of someone at work &
\end{tabular}




\begin{tabular}{lll}
\hline CWB cate- $\begin{array}{l}\text { } \begin{array}{l}\text { gories } \\
\text { Production } \\
\text { deviance }\end{array} \\
\text { Sabotage }\end{array}$ & Items & CWB-I/O \\
\cline { 2 - 3 } & Purposely did my work incorrectly & $\mathrm{O}$ \\
\cline { 2 - 3 } & Purposely failed to follow instructions & $\mathrm{O}$ \\
\cline { 2 - 3 } & Purposely wasted my employer's materials/supplies & $\mathrm{O}$ \\
\cline { 2 - 3 } & Purposely damaged a piece of equipment or property & $\mathrm{O}$ \\
\hline \multirow{4}{*}{ Theft } & Stolen something belonging to my employer & $\mathrm{O}$ \\
\cline { 2 - 3 } & Took supplies or tools home without permission & $\mathrm{O}$ \\
\cline { 2 - 3 } & Put in to be paid for more hours than you worked & $\mathrm{O}$ \\
\cline { 2 - 3 } & Took money from your employer without permission & $\mathrm{O}$ \\
\cline { 2 - 3 } & Stole something belonging to someone at work & $\mathrm{I}$ \\
\hline \multirow{3}{*}{ Withdrawal } & Same to work late without permission & $\mathrm{O}$ \\
\cline { 2 - 3 } & Stayed home from work and said you were sick when you weren't & $\mathrm{O}$ \\
\cline { 2 - 3 } & Taken a longer break than you were allowed to take & $\mathrm{O}$ \\
\cline { 2 - 3 } & Left work earlier than you were allowed to & \\
\hline
\end{tabular}

COUNTERPRODUCTIVE

WORK

BEHAVIOR

Dawid Szostek

Source: own elaboration based on: http://shell.cas.usf.edu/ pspector/scales/cwbcpage.html.

\section{Appendix 2. Charts 1-8: the aggregate frequency of CWB (including categories and dimensions of CWB) divided into public and private sector employees}

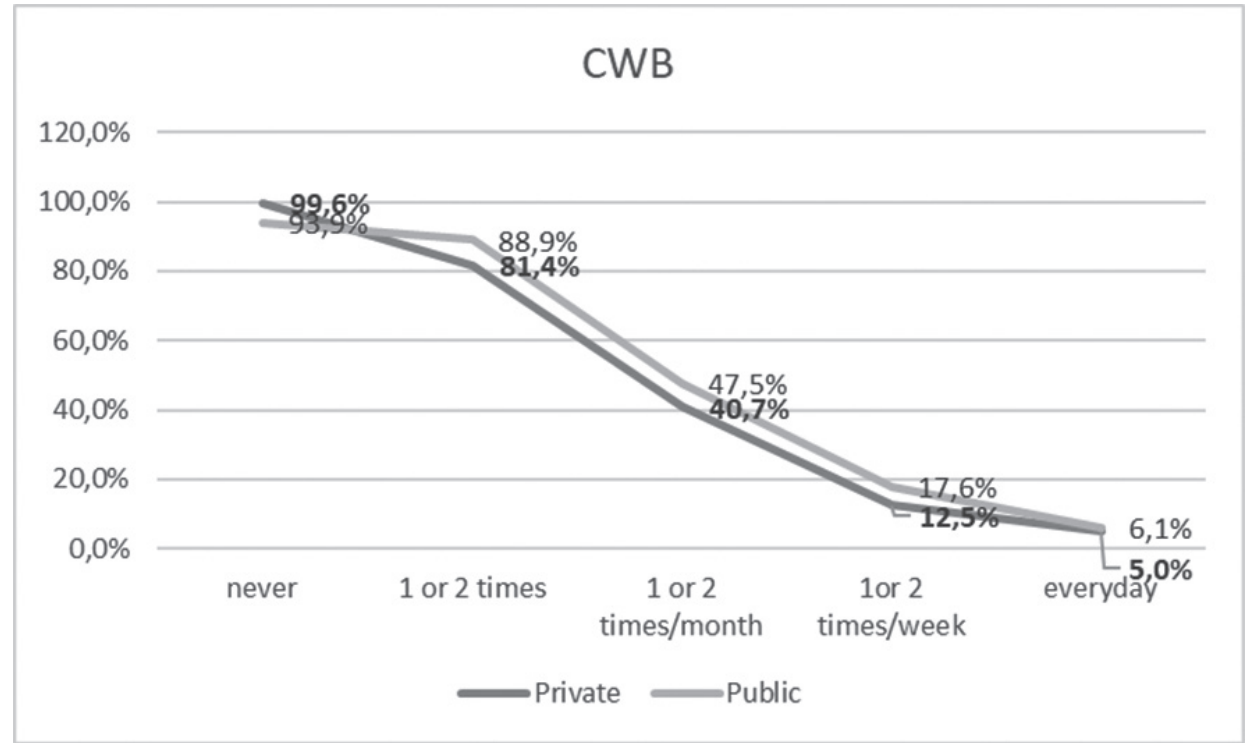

Chart 1.

Source: own study. 
COUNTERPRODUCTIVE

WORK

BEHAVIOR

Dawid Szostek

\section{Chart 2.}

Source: own study.

\section{Chart 3.}

Source: own study.

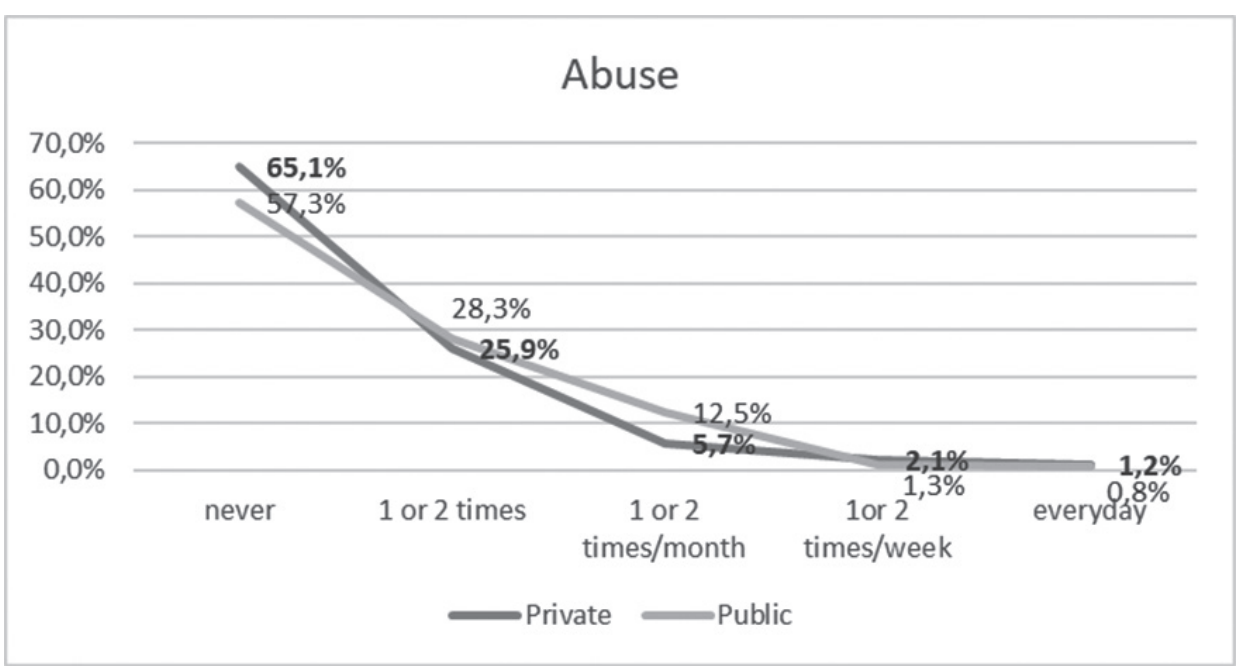

\section{Production deviance}

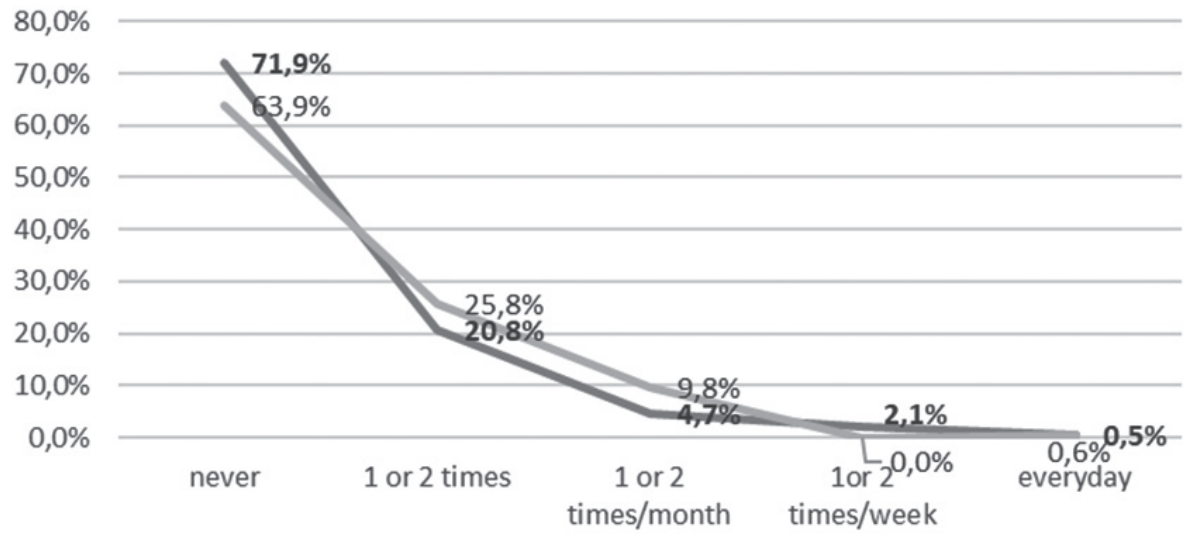

$\longrightarrow$ Private $\longrightarrow$ Public 


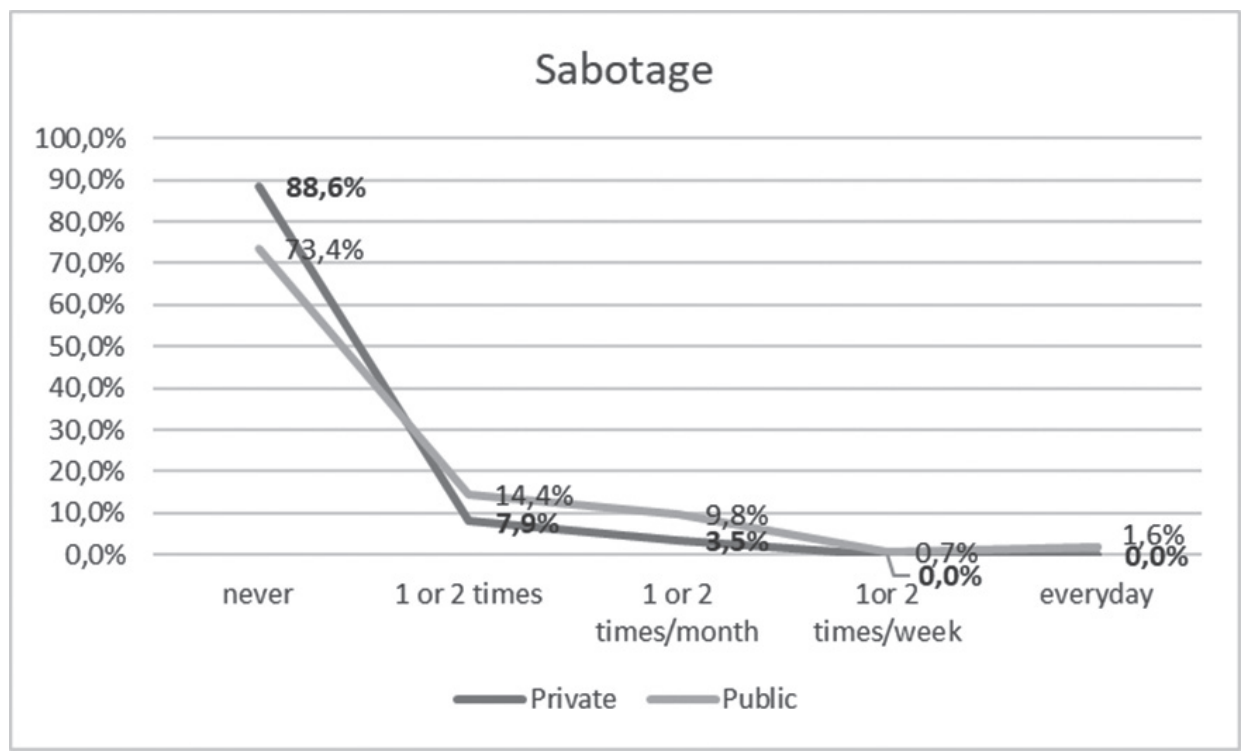

Dawid Szostek

Chart 4.

Source: own study.

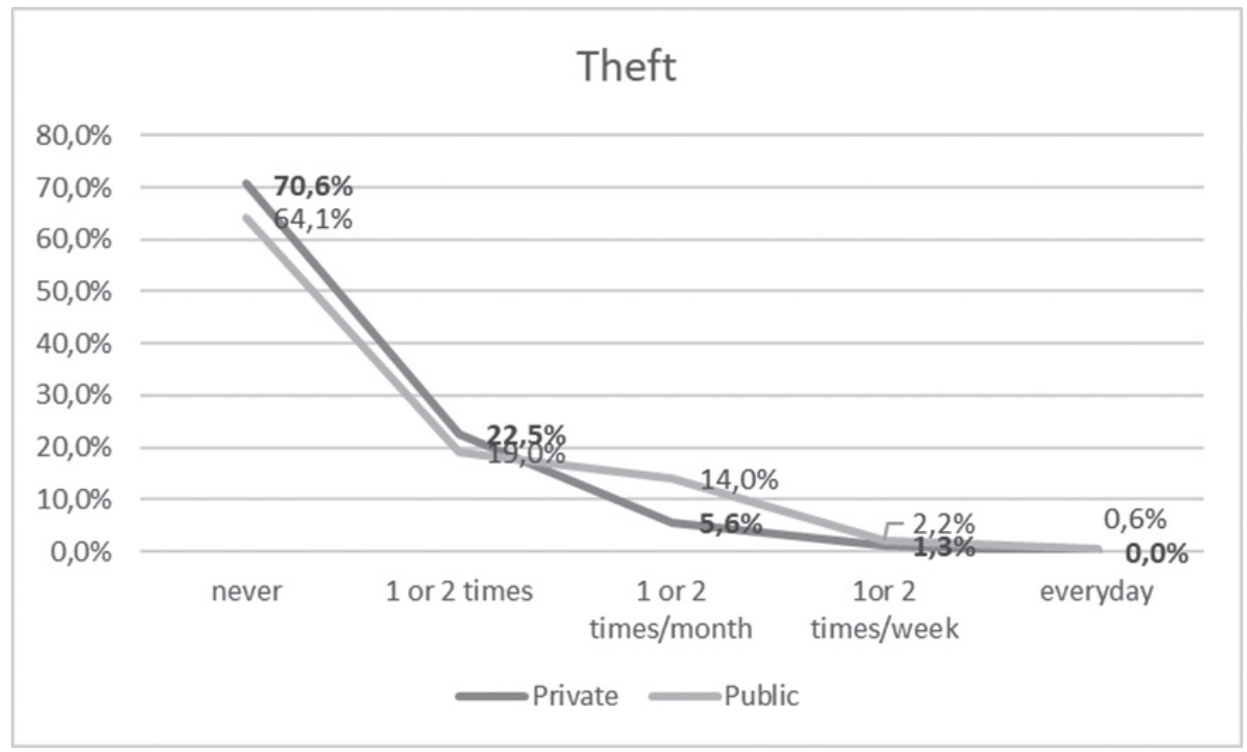

Chart 5.

Source: own study. 
COUNTERPRODUCTIVE

WORK

BEHAVIOR

Dawid Szostek

\section{Chart 6.}

Source: own study.

\section{Chart 7.}

Source: own study.

\section{Withdrawal}

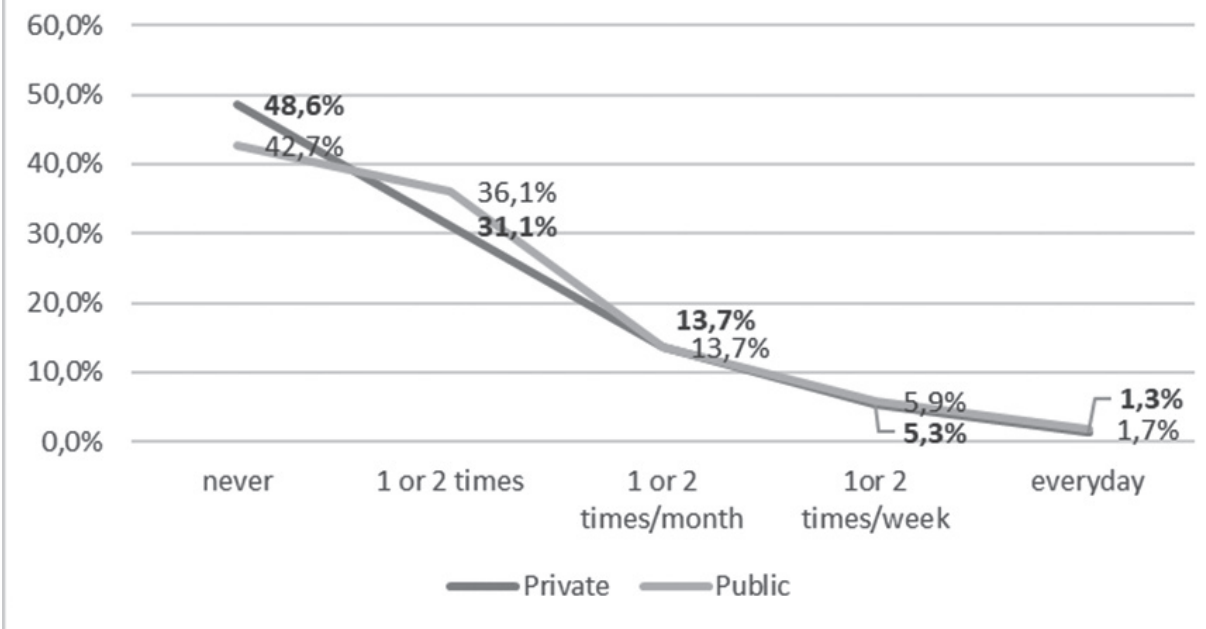




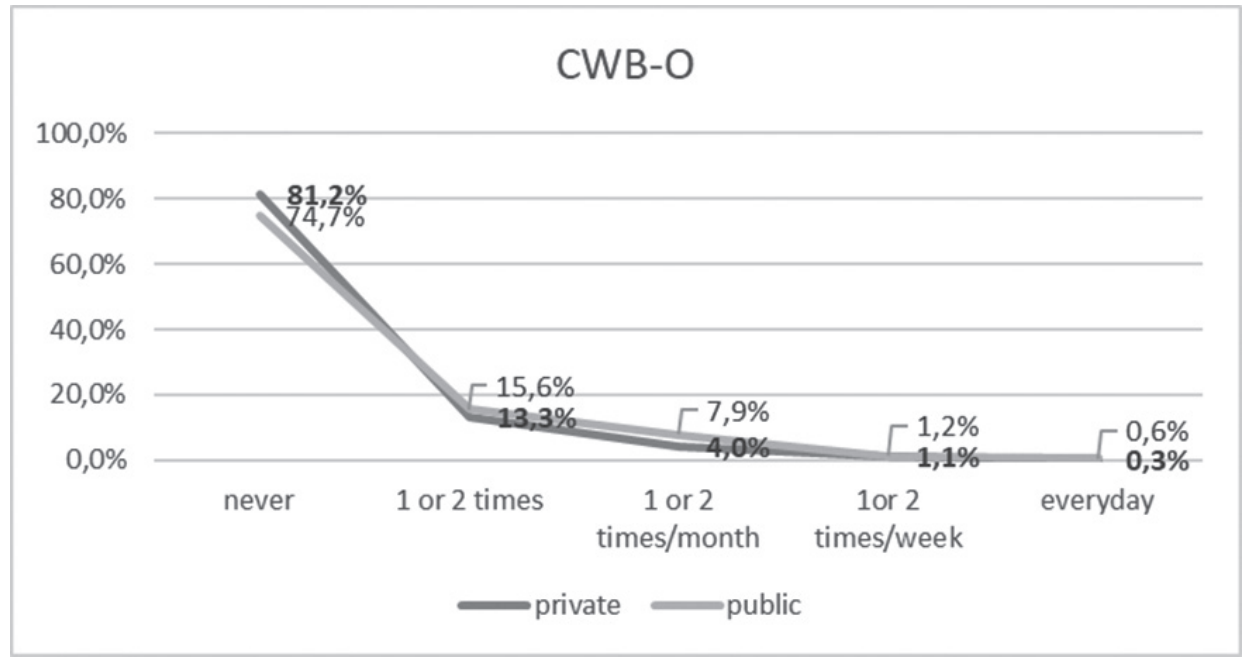

Chart 8.

Source: own study. 